Ien geweldigen smid, die dit in de hitte der stormachtige bewegingen des tijds steeds omsureedt naar de steeds veranderde behocften.

C. $T$.

\section{WAARDEERING VAN GEBRUIKSGOEDEREN}

De wardeering van gebruiksgoederen wordt beheerscht door de vraag: moet de balans het vermogen van een ondernening aanwijzen of de winst, sinds de vorige balans behaald?

In het algemeen wordt in vakkringen de meening gehuldigd, dat de balans de winst, in de afgeloopen periode behaald, moet aanwijzen, de gebruiksgoederen voor kostprijs, verminderd met a.fschrijving, moeten worden opgenomen.

1/no zegt Spicer and Pegler: (blz. 133)

,Such assets should be shown in the Balance Sheet at cost mice, less any depreciation that may have taken place. The net figure will represent the present value of the assets to the business as a going concern. It is not necessary to take into account the marketvalue of Fixed Assets, which may be subject to considerable fluctuation. ........... Tn the event of a foreed realisation, heavy losses would probably ensue, but it would not be reasonable to anticipate such losses before arriving at the current profits of the business."

\section{Dicksee, Auditing blz. 188.}

"On the other hand, Fluctuation is something altogether apart from trading profit and loss, being merely an accidental variation in the value of certain property owned but not tradet in : to cary the amount of such variations to Profit and Loss Account would be disturb and obseure the results of actual trading and to render comparison difficult, if not impossible. Moreover as has already been stated, the Profit and Loss Account should be so framed as to show a balance with actually exists and is properly available for dividend."

Prof. I. (:. Ch. Volmer, Winstrekening en Vermogensbalans, bIz. 46

„Met betrekking tot deze groep (vaste bezittingen) van activa is men eenstemmig van meening, dat men bij de waardebepaling moet uitgaan van den kostenden prijjs.

Bij gebouwen en in het algemeen bij zaken, waarvan de warlde door het gebruik of door het verloop van tijd achteruit gaat, moet met die waardevermindering rekening gehouden worden. Men noemt dit afschrijven."

\section{v. Arkel, pag. 60}

,Bij het bepalen van het stamvermogen zal men rekening moeten houden met de diensten, die het stamvermogen aan het bedrijf bewijst. Er noet naar gestreefd worden, dat ten laste van elke periode wordt gebracht een bediag, dat aan die diensten evenredig is."

\section{G. P. J. Hogeweg, Accountantsdag 1912.}

„Met waardeschommeling van terreinen enz. mag geen rekening worden gehouden."

Ook de l)uitsche wetgever gaat $b i j j$ het geven van regelen voor de wardeering van gebruiksgoederen van de aanschaffingswaarde nit.

H. G. B. § 261 al. 3

„Anlagen und sonstige Gegenstände, die nicht zur Weiterveräusserung, viel mehr dauernd zum Geschäftsbetriebe der
Gesellschaft bestimmt sind, dürfen ohne Rücksicht auf einen geringeren Wert, zu dem Anschaffings- oder Herstellungspreis angesetzt werden, sofern ein der Abnutzung gleichkommender Betrag in Abzug gebracht oder ein ihr entsprechender Erneuerungfonds in Ansatz gcbracht wird."

Eigenaardig doet het daarom aan, dat het Reglement van Arbeid $\mathrm{v} / \mathrm{h}$ Ned. Inst. v. Accountants een andere meening huldigt. In art. 7 , waarin het balansonderzoek wordt omschreven, komt o.m. het volgende voor:

"Indien een lid, op grond van het vorenomschreven, van oordeel is, dat de balans een juist beeld geeft van den toestand van het vermogen, waarop die balans betrekking heeft, onderteekent hij de balans, al of niet onder toevoeging eener toelichtende verklaring.

Een dusdanige goedkeuring der balans strekt zich ten opzichte van het bestaan der koopmansgoederen en gebruiksbezittingen, zoomede ten opzichte van de waardeering dier goederen en de afschrijvingen op die bezittingen, nict verder uit, dan van den niet-terzake-kundige verlangd kan worden."

Het Reglement van Arbeid stelt zich dus op hetzelfde standpunt als ,the man in the street": de balans moet het vermogen van de onderneming aangeven.

Voorheen was hiertegen minder bezwaar. Weliswaar was ook toen nimmer de ,waarde" (inkoop-, verkoopprijs, liquidatiewaarde?) van een gebruiksgoed gelijk aan de aanschaffingswaarde, verminderd met afschrijvingen, doch het verschil was in 't algemeen nimmer groot. Waarschijnlijk is aan deze omstandigheid de redactie van art. 7 van het Reglement van Arbeid te wijten.

Thans echter is het gansch ander's gesteld. En door het stijgen van de waarde van den gulden vanaf 1920 , èn door de heerschende laagconjunctuur, waardoor het zelfs mogelijk is gebruiksgoederen te koopen beneden den huidigen kostprijjs, bezitten bedrịjven, welke in den zongenaamden duren tijd zijjn gesticht of uitgebreid, nu machines en gebouwen, waarvoor twee-, driemaal zoo veel is uitgegeven als de aanschaffingsprijs op dit oogenblik zou bedragen.

Kan nu een accountant een balans onderteekenen, waarin gebruiksgoederen, in den duren tijjd gekocht, voor de aanschaffingswaarde, verminderd met normale afschrijvingen, voorkomen?

Volgens het Reglement van Arbeid niet, volgens de vakpers echter wel. De vermenging van vermogensvermeerderingen of -verminderingen met inkomen kan niet worden toegestaan, wil men een juist beeld krijgen van de earning-power der onderneming.

Waar, zooals ik hierboven reeds opmerkte, thans zulke groote verschillen voorkomen, lijkt het mij van het grootste belang, dat spoedig het Reglement van Arbeid van het Nederl. Inst. v. Acc. op dit punt worde herzien.

\section{STARKF}

(Wij meenen, dat de gachte inzender ten onrechte aanneemt, clat het door hem aangehaalde artikel van het Reglement van Arbeid van het N.I.v. $\Lambda$. en aanwjizing geeft omtrent de wijze, waurop het vermogen van de ondernening moet worden berekend. Ook, indien echter zulks wel het geval zou zijn en er inderdaad een tegenstelling zou bestaan tusschen de in dit Reglement gehuldigde opvatting en die van de geciteerde schrijvers, zou hieruit o.i. nog niet volgen, dat het Reglement wijziging behoeft. Het is immers niet ommogelịk, dat bij nadere beschouwing de opvatting dier schrijver's onjuist zou blijken. Anderzijds gelnoven wij, dat niet vaststalat, dat de door den heer $\mathrm{S}$. uit de de gedane aanhalingen getrokken conclusie door alle auteurs 
als cen juiste interpretatie hunner meening zal worden aanvaard.

Het komt ons dus voor, dat het probleem anders moet worden gesteld en dat cenvoudig zal moeten worden onderzocht, of bij de opstelling der balans de warde der duurzame productie-middelen al dan niet afhankelijk is van de wijzigringen in den prijs van soortgelijke roederen op de markt.

(Red.)

\section{FISCALITEITEN}

Veelal is betoogd, dat de Dividend- \& Tantièmebelasting de voorkeur verdiende boven een winstbelasting voor Naamloozc Vennootschappen op dezen grond, dat bij eerstgenoemde belasting rich weinig kwesties zouden voordoen.

Steeds stijgt echter het aantal heslissingen en nitspraken opgenomen in de Beslissingen in Belastingzaken, die natuurlijk slechts als typen zijn to beschouwen ran de door de Raden van Beroep behandelde zaken.

Een belangrijk aandecl wordt gevormd door de, wat men zou kummen noemen, feitelijke zaken, d.w.z. dic gevallen, waarin el geen geschil bestaat aangaande hetgeen geschiedde, nóch aangaande de kwestie, of er nail den vorm aanleiding bestond voor een aanslag, doeh alleen hierover. of de vorm inderdaad aansloot aan de feiten.

Fen bestudeering van de verschillende beslissingen wijst er op, dat in vele gevallen de Raden van Beroep zich niet bepaaIden tot de vraag hoe de vorm zich verhield tot de wet. maar zich wel degelịk afvroegen, of de vorm in overeenstemming was met de werkelijkheid.

Een voorbeeld van zulk een geval is te vinden in B. 3136 .

In een der vele miniatuur-bouwmatschappijen met cen aandeelenkapitaal van slechts $f 13.000$. - was het a andeclenkapitaal geheel in handen van leden van den Rad van Bestuur, de Hecren A. en B. en hume respectievelijke echtgenooten, dic daarvoor gezanenlijk $f 3000$ salaris genoten. De Inspecteur had het niet aannemelijk geacht, dat de geheelc winst nitgekecrd zou zijn als salaris en had aangenomen, dat $f 2000$ te beschouwen was als uitdeeling aan andeelhouders.

De Raad ran Berocp verwicrp het beroepschrift en nam aan, dat, gezien den aard en den kleinen omvang van het bedrijf een salaris van $f$ 1000, - aan de gezamenlijke leden van den Raad van Bestuur voldoende is te achten als belooning voor de door hen verrichte werkzaamheden.

Hicrtegnover werd in cassatic aangevoerd, dat de Raad van Beroep, waar de Algemeene Vergadering van aandeelhouders het salaris bepalde op $f 3000$, niet die som mocht splitsen in een bedrag van $f 2000$ als uitkeering aan aandeelhouders en $f 1000$ als belooning voor verrichte werkzaamheden, omdat wat rechtens als salaris wordt toegelend niet slechts zoo wordt genoemd, maar dit ook is en dat de fiscus zich dus hieraan heeft te houden.

Zooals men ziet is het standpunt van bel.pl. scherp gesteld. De algemeene vergadering de bevoegde macht in de N.V. heeft een bepaald besluit genomen, wartoe zij.j bevoegd was, dus is dit besluit onaantastbaal.

De Hooge Raad was het hier echter niet mee cens en besliste, dat het zeer zeker den fiseus nict zou vrijstaan om in verband met ziju oordeel over de omvangrijkheid der werkzamheden slechts cen deel van hetgecn werkelịk als salaris wordt genoten, als zoodanig te beschouwen. Hij laat er echter op volgen, dat de Raad van Beroep alleen had beslist, op grond van verschillende feiten, dat het niet a anmemelijk was, dat de aandeclhouders in het geheel gcen dividend hadden genoten over hm kapitaal en dat, in hetgeen aan de bestuurders, in wier handen alle aandeelen waren, was uitgekeerd. niet een gedeelte zuivere winst zou zijn. De Raad had dus enkel nagegaan, wat werkelijk was reschied. Deze uitspraak lag bimmen de bevoegdheid van den Ruad. De kwestic, of dit oor'lecl al dan niet juist was, kwam niet in aanmerking voor cassatie.

Hocwel het in dit geval slechts over een zeer gering bedrag ging, kwamen de versehillende standpunten hicr zeer scherp naar voren.

Interessant is het ook wol hierom, omdat de Gemeente Amsterdam in de dagen, dat zij de gemeentelijke Inkomstenbelasting nog zolfstandig vaststelde, er wel op androng, dat men in dergelijke N.V.'s bepaalde, dat het salaris van de Directic zou worden vastgesteld tot het hedrag van de gehecle winst. ondat deze in dat geval helastbaar was.

Fen ander voorhceld wordt behandeld in B. 3201. Het betreft hier cen geval, waarin nar meening van den fiscus gelden van de Naamlonze Vennootschap aan aandeelhouders waren uitgedeeld. MIen had namelijk an de versehillende aandeclhouders gelden in depot gegeven. Het aangaan van schulden, of het in depôt geven ervan op zichzolf was natumlijk cen handeling. wanmede de fiseus nicts te maken had. Fehter wezen verschillende onstandigheden op iets abnormaals in dit geval. Fr werd hijv. geen rente vergoed ann de N.V., er was geen termijn van terugbetaling bepaald, de ge]den waren uitsluitend aan aandeelhouders in depôt gegeven, en wel in verhouding tot hun aanderlenbezit.

Fliernit maakte de Raad ran Beroep op, dat er hier geen geldlecning had plaats gehad, doch in werkelijkheid een nitdeeling, op grond van wellke overweging de aanslag gehandhaafd bleef.

Ook tegen deze uitspraak werd cassatic aangeterkend op ongever gelijke gronden, als in het hiervoor behandelde geval, dat n.l. de sronden van den Raad het karakter van de in depôt geving niet aantasten. Ook hier wees de IIooge Raad dit betoog af, overwegende, dat de Raad van Beroep niet bedoeld had, zich uit te spreken over het karakter van het in depôt geven van gelden. maar enkel besliste dat de bepaalde transactie slechts in naam tot stand kwam welk oordeel niet voor cassatie in aanmerking komt, daar dit oordecl ran feitelijken aard is.

Hieraan voegt hij nog toe, dat de Raad zekel voor wettig tot stand gekomen handelingen niet zonder wettige gronden andere in de plats mag stellen om daarop belasting te heffen, maar dat anderzijds niets er zich tegen verzet, dat belasting worde geheven van wat werkelijk en niet in schijn tusschen partijen is geschied, waneer dic sehijn on die werkelịkheid afdoende zijn gebleken.

Het is duidelijk, dat in dergelijke gevallen meestal de beslissing berust bij den Raad van Berocp, daar deze zal moeten zeggen, of de gronden hem al of niet voldoende voorkomen, hetgeen uiteraard leidt tot cen feitelijke uitspraak.

Wen zeer belangwekkend geval is de bekende aanslag van de Koninklijke I'etroleum Maatschappij in de Dividend- en Tantièmebclasting over het jaar 1918, waar de Hooge Raad tot tweemaal toe de uitspraak van den Raad van Beroep in het roordeel der Maatschappij casseerde en eindigde den aanslag ambtshalve te handhaven.

De Koninklijke bezat $60 \%$, de Shell $40 \%$ van het aandeelenkapitaal der Hollandsche en Engelsche dochtermaatschappijen van het eoncern en declden dus ook in deze verhouding in de winsten ervan. Dool een statutenwijziging werd bepaald, dat van 1917 af de Koninklijke $95 \%$ van de winst der Hollandsche dochtermaatschappij zou ontvangen, de Shell $95 \%$ der winst van de Engelsche. 1Tierdoor reeds had gedeeltelijk compensatic plaats, doordat wat de bejde maatschappijen minder ontvingen uit de vreme dochternaatschappijen vergoed werd door hetgeen zo neer van de in het binnenland gevestigde ontvingen. Bo- 